\title{
Pollination and breeding system in two sympatric Fuchsia (Onagraceae) species at the Parque Nacional do Itatiaia (Brazil): Hummingbirds, insects and facultative self-pollination'
}

\author{
Patricia Archer ${ }^{2}$ (D), Oscar Perdomo ${ }^{3}$ (i), Tiago Böer Breier ${ }^{(1)}$, \\ André Felippe Nunes-Freitas ${ }^{5}$ (D), Rodrigo B. Singer ${ }^{6, *}$ (D)
}

\begin{abstract}
'Part of the M. Sc. Dissertation of the first author, Programa de Pós-Graduação em Ciências Ambientais e Florestais-UFRRJ. 2 Programa de Pós-Graduação em Ciências Ambientais e Florestais-UFRRJ. Current address: $4719 \mathrm{E}$. Amber road, Prescott AZ, 86301 , USA. ${ }^{3}$ Laboratório de Sistemática de Plantas Vasculares, Depto. Botânica, IB, UFRGS. Av. Bento Gonçalves 9500. CEP 91501-970. Programa de Pós-Graduação em Botânica, UFRGS, Porto Alegre, RS, Brasil. ${ }_{4}^{4}$ Departamento de Silvicultura, IF, UFRRJ. BR 465, km 7, CEP 23897-000, Seropédica, RJ, Brasil. ${ }^{5}$ Departamento de Ciências Ambientais, IF, UFRRJ. BR 465, km 7, CEP 23897-000, Seropédica, RJ, Brasil. ${ }^{6}$ Departamento de Botânica, IB, UFRGS. Programa de Pós-Graduação em Botânica, UFRGS, Porto Alegre, RS, Brasil. *Corresponding author: rbsinger1@yahoo.com
\end{abstract}

\begin{abstract}
Fuchsia regia and F. campos-portoi (Onagraceae) belong to section Quelusia; a group native to the Patagonian, Southern and Southeastern Brazilian regions. To date, no studies coupling detailed pollinator observations and breeding system experiments have been published for these species. Studies were performed at the Parque Nacional do Itatiaia (Rio de Janeiro), in altitudes ranging from 1300 to 2790 meters a.s.l. The flowers are nectariferous and protogynous. Yet, both species are self-compatible and facultatively autogamous, since more than $43 \%$ of the intact flowers undergo delayed self-pollination. Hummingbirds (four species), Acroceridae flies and bees (Apis mellifera and Bombus brasiliensis), in that order of importance, were recorded as pollinators of $F$. regia. In F. campos-portoi, bees of B. brasiliensis were the most frequent pollinators, followed by hummingbirds (three species). Experimental crosses between the two species yielded no fruits, in spite of their sharing of pollinators and of the existence of hybrids mentioned in literature.
\end{abstract}

Keywords: Bees, Fuchsia, hummingbirds, Onagraceae, pollination, Quelusia.

RESUMO - Fuchsia regia e F. campos-portoi (Onagraceae) pertencem à seção Quelusia; um grupo nativo da Patagônia e do Sul e Sudeste do Brasil. Até o momento não foram publicados estudos integrando detalhadas observações de polinização e de sistema reprodutivo neste agrupamento. Os estudos foram efetuados no Parque Nacional do Itatiaia (Rio de Janeiro), em altitudes entre 1300 e 2790 m. a.s.l. As flores são nectaríferas e protóginas. No entanto, ambas as espécies são auto-compatíveis e autógamas facultativas, uma vez que mais do que $43 \%$ das flores intactas se autopolinizam tardiamente. Beija-flores (quatro espécies), moscas Acroceridae e abelhas (Apis mellifera e Bombus brasiliensis), nesta ordem de importância, foram documentados como polinizadores de F. regia. Em F. campos-portoi, abelhas B. brasiliensis foram os polinizadores mais frequentes, seguidas de beija-flores (três espécies). Cruzamentos interespecíficos não produziram frutos, embora ambas as espécies partilhem polinizadores e a existência de híbridos seja mencionada na literatura.

Palavras-chave: Abelhas, beija-flores, Fuchsia, Onagraceae, polinização, Quelusia.

\section{INTRODUCTION}

Fuchsia L. (Myrtales: Onagraceae) is a mostly Neotropical plant genus whose higher diversity occurs in the tropical Andes (Berry et al. 2004). As a whole, the genus includes about 110 species distributed in 12 sections (Berry et al. 2004). Fuchsia is highly prized as a source of ornamental plants (Berry et al. 2004, Berry 1989), with most horticulturally important species belonging to the Fuchsia sect. Quelusia (Vand.) DC.; a group which is restricted to Patagonia (both Chilean and Argentinean), Southern and South-eastern Brazil (Berry et al. 2004, Berry 1989). Within this section, Fuchsia regia (Vell.) Munz is the most widespread species, occurring from Southern Brazil to Espirito Santo, in high altitudes of the Mata Atlântica Biome (Atlantic Rain Domain) (Berry 1989, Rodrigues \& Singer 2014), while the other seven Brazilian species have considerably more restricted distributions (Berry 1989), some of them (as F. campos-portoi Pilg. \& Schulze-Menz) being endemic. Few South American Fuchsia species have been studied regarding their pollination and breeding systems (Atsatt \& Rundel 1982, Travesset et al. 1998).

Since most species present scentless, reddish, tubulose, nectar-secreting flowers; Fuchsia is considered as primarily adapted for bird pollination (Berry 1989, Berry et al. 2004; Raven 1979). The most complete studies so far have 
shown that birds, bees and flies are, in fact, pollinators of Fuchsia species from New Zealand (Delph \& Lively 1989, Godley 1963, Montgomery et al. 2001, Robertson et al. 2008), Chile (Atsatt \& Rundel 1982, Travesset et al. 1998) and México (González et al. 2018). To the best of our knowledge, there are no detailed studies coupling breeding system experiments and accurate pollinator observations in species of Section Quelusia. Travesset et al. (1998) mention that F. magellanica Lam. is pollinated by the Patagonian hummingbird Sephanoides galeritus and that -owing to its floral morphology- the flowers of this species may be facultatively autogamous, without presenting, however, supporting information for this claim. Anecdotal observations of hummingbirds as flower visitors in F. regia (Berry 1989, Rodrigues \& Singer 2014) and F. coccinea (Berry 1989) have been published elsewhere. Yet, these reports assume that these Fuchsia species are pollinated by these hummingbirds without unequivocally ascertaining if these birds did, indeed, transfer pollen to the stigmas; a mandatory condition to consider any flower visitor as a pollinator. The notable exception is the work of Buzato et al. (2000) in a study involving three localities in São Paulo State (Brazil), representing variations of the Mata Atlântica Biome (Atlantic Rain Forest). In this study, Buzato et al. (2000) convincingly demonstrated that four hummingbird species locally pollinate the flowers of $F$. regia. However, none of these reports involving Fuchsias of sect. Quelusia addressed the actual breeding systems of the study plants (Berry 1989, Rodrigues \& Singer 2014, Travesset et al.1998).

The aim of the present contribution is to present a detailed study of the pollination needs and breeding systems of Fuchsia regia and F. campos-portoi, two species that occur in sympatry in the Itatiaia Mountains (RJ). Precedent literature (Berry 1989) suggests the existence of putative hybrids with somewhat overlapping morphology. In agreement with this, in 2009, one of us photographed a Fuchsia plant with such features, near the Base of the IBAMA, at the Itatiaia National Park (Figure 1C). The questions that promote this contribution are the following: 1) Are the plants under study pollinator-dependent in order to set fruit and seed? 2) Which are the pollinators? Do plants share pollinators? 3) What are the breeding systems of these Fuchsia species? Owing to preliminary observations and preceding literature, we proposed the following hypotheses: 1) The study plants may be pollinator-dependent, 2) Owing to overall floral features (colour, flower structure) we expect that pollinators of both species to be hummingbirds or other kinds of birds, and 3) We suggest that the study plants may be pollinator-dependent, yet also self-compatible (able to set fruit when pollinated with pollen of the same individual).

\section{METHODS}

\section{Study Area}

Studies were undertaken at the Itatiaia National Park (Parque Nacional do Itatiaia, $22^{\circ} 22^{\prime} 31^{\prime \prime} \mathrm{S}$ and $44^{\circ} 22^{\prime} 39^{\prime}$ 44" W) between September 2010 and January 2012. The Park embraces part of the territories of two Brazilian States: Rio de Janeiro (Municipalities of Resende and Itatiaia) and Minas Gerais (Municipalities of Alagoa, Bocaina de Minas and Itamonte). Altitude varies from 500 to 2791 meters a.s.l. (at the Pico das Agulhas Negras, the highest point). The region presents a mosaic of forest and rupicolous-grassy vegetation subtypes, all inserted within the Atlantic Rain Forest (Mata Atlântica) Biome. The climate is mesothermic
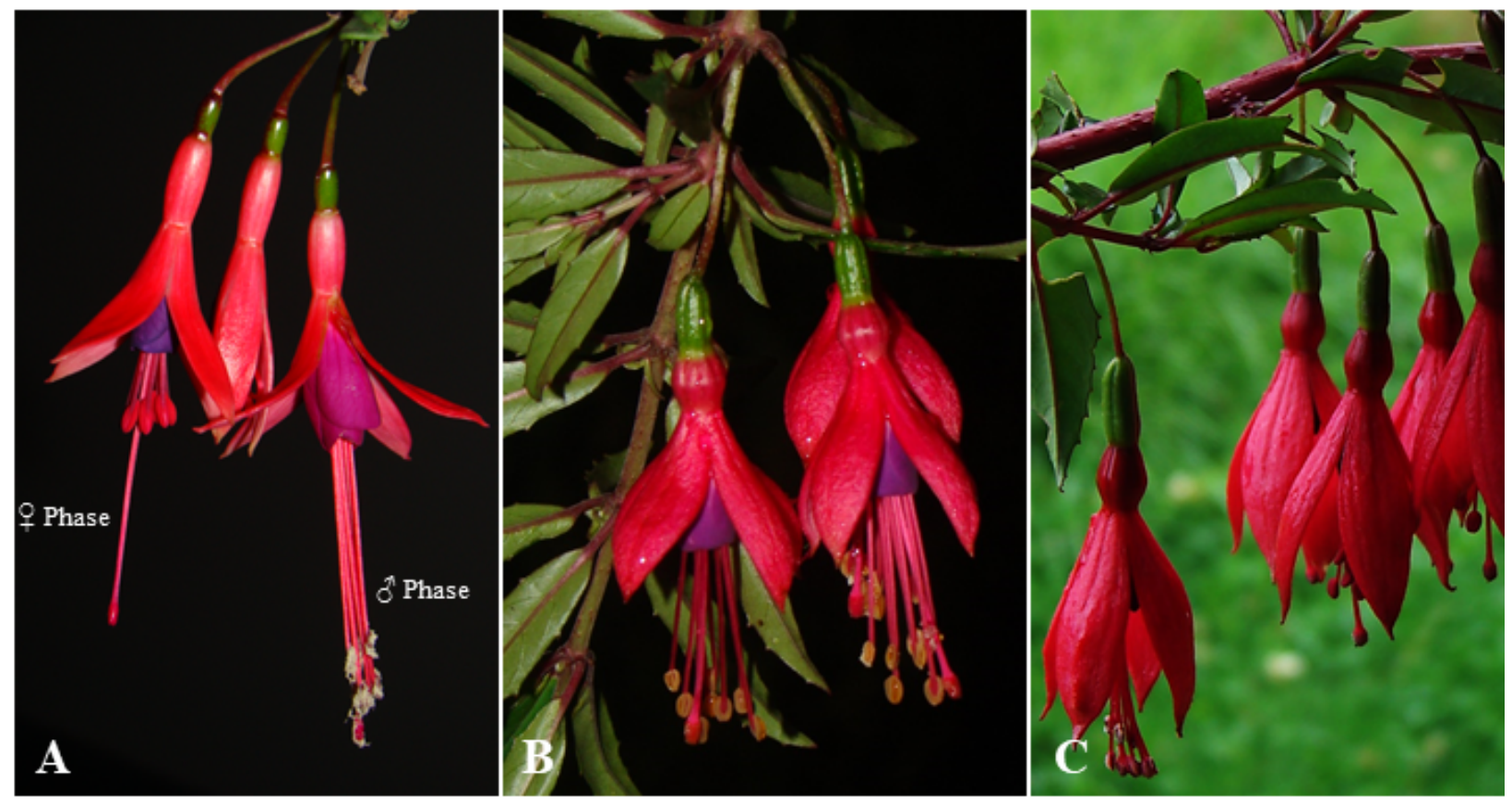

Figure 1. A. Flowers of Fuchsia regia in female (left) and male phases (right). B. Flowers of F. campos-portoi. C. Possible hybrid (F. regia x F. campos-portoi) photographed in 2009, near the IBAMA base ao the Itatiaia National Park. 
(Cwb type of Köppen), with hot and rainy summers and cold and dryer winters. Annual rainfall reaches $2400 \mathrm{~mm}$ and annual mean temperature is $14 \mathrm{C}$. The seasonality of rains renders winter fires relatively frequent.

\section{Studied species}

We studied the pollination biology of Fuchsia regia and F. campos-portoi (Onagraceae). Both species are currently classified within Section Quelusia, a well-supported Clade that dwells in Chilean and Argentinean Patagonia, as well as in Southern and Southeastern Brazil (Berry 1989, Berry et al. 2004). In the latter country, all species thrive at altitudes higher than 800 meters a.s.l. (Berry 1989). Both studied species share some important features: the flowers are epigynous, pendulous (Figure 1) and nectariferous (Buzato et al. 2000). A fully developed flower of $F$. regia reaches ca. $7.5 \mathrm{~cm}$ in total length, whereas these of F. campos-portoi are much shorter, reaching up to $4 \mathrm{~cm}$ (Berry 1989). In both species the calyx is tetramerous and reddish, with the sepals being connate at their bases (Figure 1). The petals are unguiculate and partially hidden by the sepals (Figure 1). In both species, petal colour changes from dark purple to lilac, as the flowers age (Figure 1A) (Rodrigues \& Singer 2014). The flowers are protogynous (act as pollen receivers first and as pollen donors later) (Berry 1989, Rodrigues \& Singer 2014). The flowers present eight stamens that are closed in just opened flowers, pollen release starting when petal color turns lighter (Rodrigues \& Singer 2014) (Figure 1A). Fruits are dark berries in both species, those of $F$. regia being smooth and those of $F$. campos-portoi being somewhat verrucose (Berry1989). Among Brazilian Fuchsia species, F. regia is the most widespread, occurring from Rio Grande do Sul to Espirito Santo, always associated with forests or grassy-rupicolous areas within the Atlantic Rain Forest Biome (Mata Atlântica) (Berry 1989). This species may vary from a shrubby (up to $2 \mathrm{~m}$ high) to a climbing habit (Berry 1989) and mostly occurs in well-exposed areas at the border of the forest. Leaves are normally opposite, but eventually can be whorled. Fuchsia campos-portoi is among the most recently described species within Section Quelusia (Pilger \& Schulze 1935). These plants are endemic to the Itatiaia Park and nearby regions, in altitudes higher than 2200 meters a.s.l. (Berry 1989, Pilger \& Schulze 1935). Plants are normally shrubs reaching $150 \mathrm{~cm}$ high, that thrive in open, sunny areas. Leaves are normally whorled and much smaller than those of $F$. regia. Plant specimens are deposited at the Herbarium of the Universidade Federal Rural do Rio de Janeiro (RBR).

\section{Floral features, flower lifespan and nectar presence}

Flower features (colour changes, pollen release) were recorded with the help of a digital camera. Flower lifespan, colour changes and other eventual changes were ascertained by monitoring intact flowers $(\mathrm{n}=60$ for $F$. regia and $\mathrm{n}=$ 39 for $F$. campos-porto $i$; the same flowers used to test the presence of automatic self-pollination; see Breeding system and Table 1). To ascertain the presence of nectar, ten buds of each species were excluded (bagged) from visitors and/ or pollinators. After one day of blooming, these protected flowers were checked. Nectar was extracted with the help of a microsyringe and concentration (total sugars) was verified with a pocket refractometer. Stigmatic receptivity was tested by means of dripping oxygen peroxide (Kearns $\&$ Inouye 1993) on the stigmatic surface of 10 flowers of each species. Bubbling stigmas are considered receptive (Kearns \& Inouye 1993).

\section{Breeding system}

In order to establish whether the study plants are pollinator-dependent, bagged flowers were used on experiments of controlled pollinations. Thirty plants of $F$. regia and twenty-one of of $F$. campos-portoi were used in these experiments (Table 1). As a whole, 272 flowers of F. regia and 162 of F. campos-portoi were used for the controlled pollinations. The Table 1 shows the number of flowers used in each treatment, per species. In all cases, flowers were bagged in pre-anthesis (bud) and the protection was either only removed when fruits were mature or when it was verified that the flower wilted. Four treatments were applied, following Kearns \& Inouye (1993): 1) intact flowers (test for automatic self-pollination), 2) emasculation (test for apomixis), 3) manually self-pollinated flowers (test for self-compatibility) and 4) cross-pollination. Additionally, 20 crosses between $F$. regia and F. camposportoi were made. This latter treatment was performed because literature (Berry 1989) mentions the existence of putative hybrids between $F$. regia and $F$. campos-porto $i$ in the Itatiaia Mountains. The results of the breeding system experiments were compared through a Pearson's Chi-squared test with simulated p-value (based on 2000 replicates), because two of the expected values were less than five. The tests were developed in Rstudio (RStudio Team, 2018). In addition, to compare the results obtained through self- and cross-pollination, we transformed the data of the treatments in a binary table (fruiting/not fruiting) and applied a Q-cochran Test, an extension of the McNemar

Table 1. Fruit-set (\%) after controlled pollinations in Fuchsia campos-portoi and F. regia, at the ParqueNacional do Itatiaia. Numbers in parentheses: fruits obtained/number of flowers used in each treatement. (NS) Non-significant.

\begin{tabular}{|c|c|c|c|c|c|c|c|}
\hline Especies & $\mathrm{N}$ & Intact flowers & Emasculation & Self-pollination & Cross-pollination & $\begin{array}{c}\text { Open } \\
\text { pollination }\end{array}$ & $\begin{array}{c}\text { Q-Cochran Test } \\
\text { self } x \text { cross }\end{array}$ \\
\hline $\begin{array}{l}\text { Fuchsia } \\
\text { campos-portoi }\end{array}$ & 21 & $53,8(21 / 39)$ & $0(0 / 30)$ & $74,2(23 / 31)$ & $88,9(32 / 36)$ & $88,9(32 / 36)$ & $\begin{array}{c}\mathrm{Q}=0,2 \\
\mathrm{p}=0,5637(\mathrm{NS})\end{array}$ \\
\hline Fuchsia regia & 30 & $58,3(35 / 60)$ & $3,6(2 / 56)$ & $77,6(45 / 58)$ & $87,3(48 / 55)$ & $77,4(41 / 53)$ & $\begin{array}{c}\mathrm{Q}=0,3333 \\
\mathrm{p}=0,5673(\mathrm{NS})\end{array}$ \\
\hline
\end{tabular}


test, which is used when the variable is dichotomous. The test was performed in Rstudio (RStudio Team, 2018) with the package "RVAideMemoire" (Hervé \& Hervé 2020). To ellucidate the fruiting success under natural conditions (open pollination), 53 flowers of $F$. regia and 36 of $F$. campos-portoi were left unbagged and, thus, exposed to the pollinators (Table 1).

\section{Pollinator observations}

For the purposes of this contribution, only animals able to effectively contact the fertile whorls (anthers and stigma) are considered pollinators. Emphasis will be given to these animals and their behaviour at the flowers. Animals that do not contact the flower's fertile parts are considered non-pollinating floral visitors and their behaviour will be mentioned briefly. The pollen in Fuchsia is characteristically "beaded" (Figure 2B and F), this is, agglutinated by large viscin threads (Berry 1989). Consequently, it is macroscopically visible and large amounts of pollen can be noticed onto the pollinators (see Results and Figure 2A-D and E-F), a fact that much facilitates the identification of actual pollinators either in
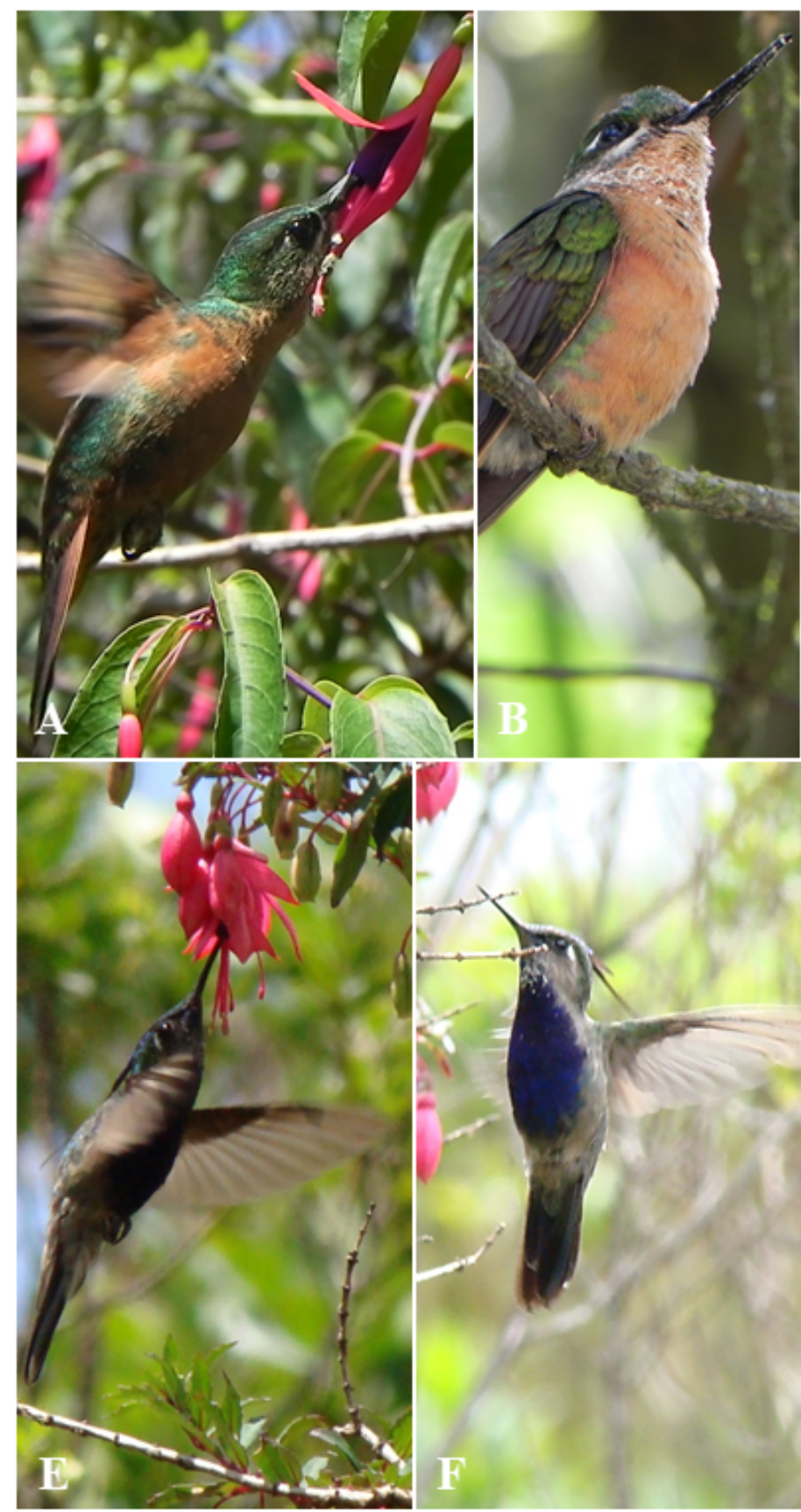
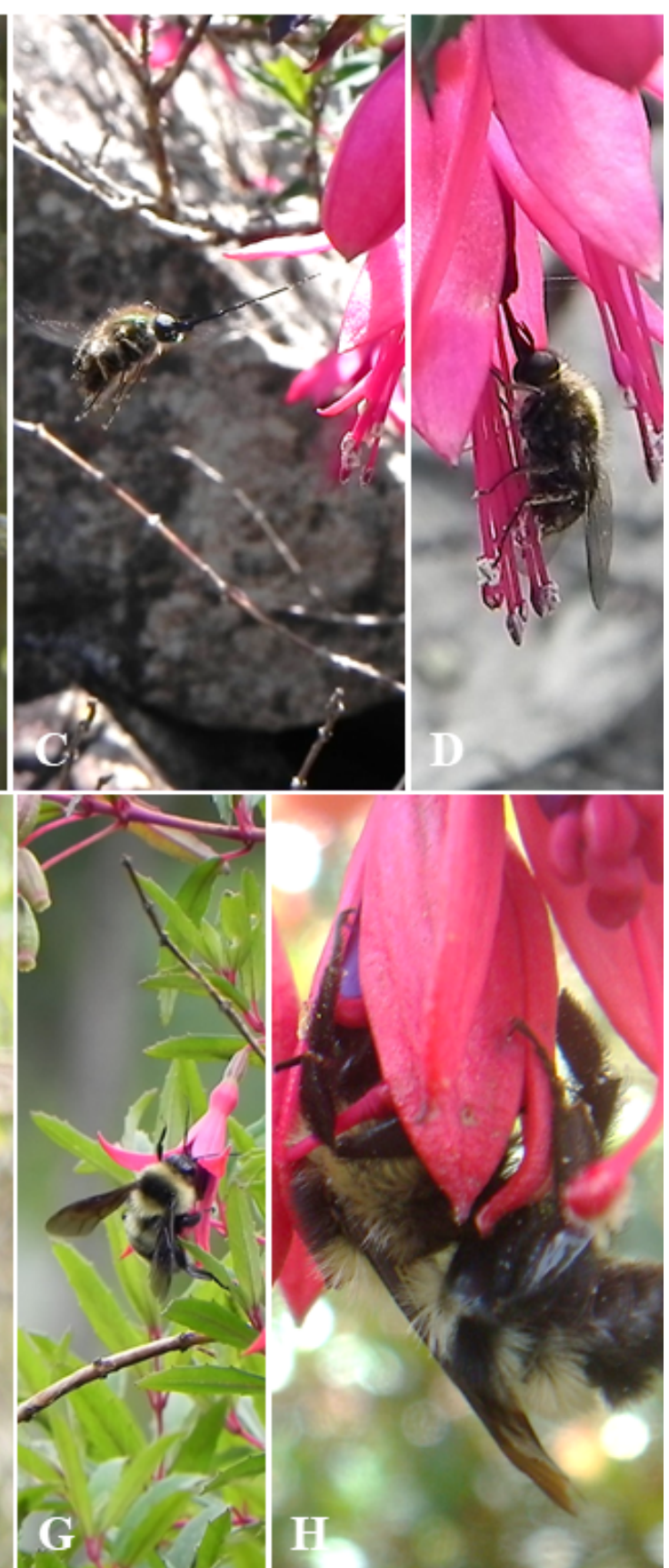

Figure 2. A-D. Pollinators of F. regia. A and B. Clytolaema rubricauda (Trochilidae) showing large amounts of pollen of $F$. regia on the throat (B). C and D. Acroceridae flies. E-H. pollinators of F. campos-portoi. E. and F. Stephanoxis lalandi (Trochilidae). Notice the pollen onto the throat (F). G. and H. Bombus brasiliensis (Apidae). Notice the stigmatic surface touching the bee's ventral region $(\mathbf{H})$. 
photographic or video records (Figure 2A-D and E-F). All animals were recorded with a digital photographic camera and eventually filmed, to better understand and characterize their behaviour at flowers. Birds were identified with the help of the literature. A few insects were euthanized so that they could be identified by specialists. Since the flowers of both species present attributes characteristic of diurnal pollination (such as colourful reddish flowers), only diurnal observations were performed.

Observations were conducted between 06:00 and 18:00 hrs. Prior to the observations, three altitudinal ranges representing three different vegetation subtypes of the Park were established: range 1 (1700-1900 m; representing the "Floresta Ombrofila Densa Alto Montana"), range 2 (2100-2300 m; representing the ecotone between the "Floresta Ombrofila Densa Alto Montana" and the "Campos de Altitude") and range 3 (2400-2790 m; "Campos de Altitude"). For F. regia, a total of 73 hours and $30 \mathrm{~min}$ were spent in observations, distributed as follows: $24 \mathrm{hrs}$ at the range $1 ; 28 \mathrm{hrs}$ at the range 2 and $21 \mathrm{~h} 30 \mathrm{~min}$ at the range 3. Since $F$. campos-portoi doesn't occur in the range 1 (altitudes between 1700 and $1900 \mathrm{~m}$ ), observations in this species were made at the other two ranges only. This species was observed for a total of 50 hours, distributed as follows: 24 hours at range 2 and 26 hours at range 3. For both species, within each altitudinal range, focal plants were observed for $15 \mathrm{~min}$ intervals. Between two and four hours per day were spent in pollinator observations. A minimum distance of $3 \mathrm{~m}$ from the plants was established, in order to avoid disturbing the animals and their normal behavior.

In order to ascertain if the pollinator assemblages and their behaviours differ, we tested the association between the number of pollination events, the number of flowers visited and the ratio pollination event / number of flowers visited observed for each kind of pollinator of the two studied Fuchsia species. Additionally, we tested these associations among the principal observed groups of pollinators, hummingbirds and Bombus brasiliensis, to establish if their pollinator importance differs between the two Fuchsia species. For all these comparisons we used the Pearson's Chi-squared test with Yates' continuity correction, alternating the use of the Pearson's Chi-squared test with simulated p-value (based on 2000 replicates), when one or more of the expected values were less than five. All tests were developed in Rstudio (RStudio Team, 2018). We used the data of the number of pollination events and number of flowers visited (Table 3) to calculate the Importance Value Index (IVI) (Figure 3) for the pollinators of both Fuchsia species, following the calculations detailed in Table 2.The IVI has been recently used to ascertain the importance of different pollinators in apple orchards (Abidin et al. 2013).

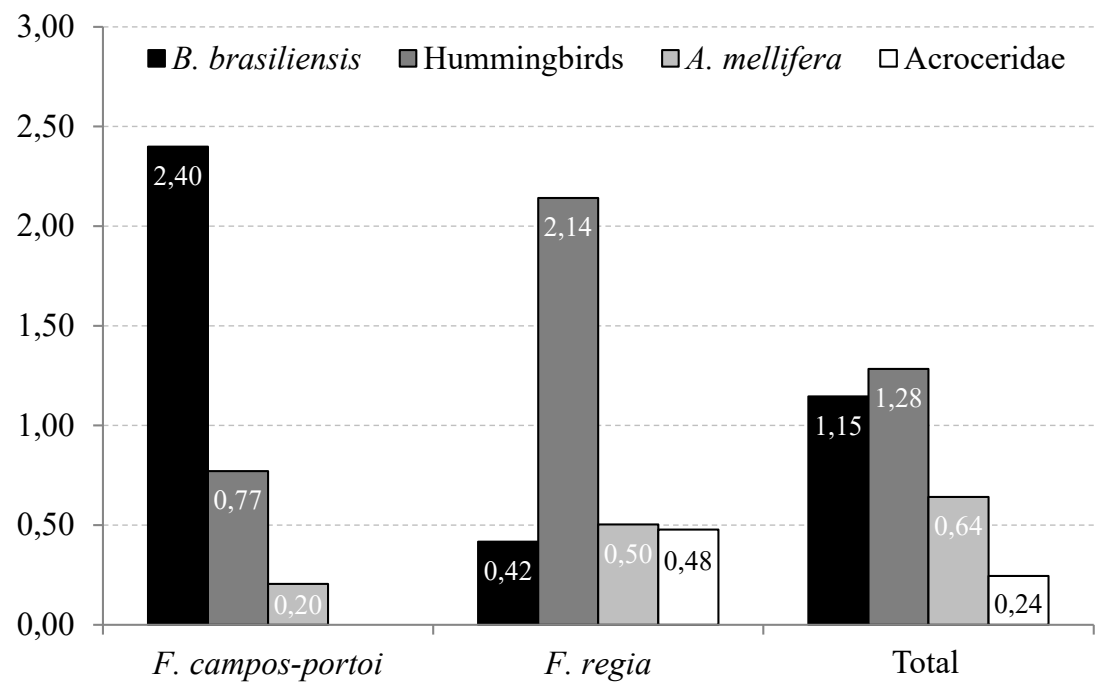

Figure 3. Importance Value Index (IVI) for the pollinators of Fuchsia campos-portoi, F. regia, and the overall for both species (Total).

\section{RESULTS}

Floral features, flower lifespan and nectar properties

Only floral features pertinent to the pollination process will be presented. Readers interested in a more detailed morphological description of the flowers are referred to Berry (1989). Both studied species share a number of floral features pertinent to the pollination process: the lifespan of intact flowers reaches 6 days in F. regia and 7 days in F. campos-portoi, after which the perianth falls. Flowers are protogynous (acting first as pollen receivers) (Figure 1A). Just opened flowers present a shiny, brilliant stigmatic surface which is already receptive, according to the peroxide test (Figure 1A). At this phase, the stamens are closed (Figure 1A). In both studied species, pollenrelease normally starts on the third day of anthesis. 
Table 2. Components of the Importance Value Index (IVI) applied to the visitation of the pollinators of Fuchsia campos-portoi and F. regia at the Parque Nacional do Itatiaia.

\begin{tabular}{lll}
\hline Index & \multicolumn{1}{c}{ Components } & Formula \\
\hline Proportion of visits in a single species & pv: pollinator visits in a single species & PV $=\mathrm{pv} / \mathrm{V}$ \\
Proportion of the total of visits & V: total of visits in the species & $\mathrm{PVT}=\mathrm{pv} / \mathrm{TV}$ \\
& $\mathrm{pv}$ : visits of the pollinator & $\mathrm{PF}=\mathrm{pfv} / \mathrm{FV}$ \\
Proportion of flowers visited in a single species & $\mathrm{pfv}$ : flowers visited by the pollinator & $\mathrm{PFT}=\mathrm{pfv} / \mathrm{TFv}$ \\
Proportion of the total of flowers visited & $\mathrm{Fv}:$ flowers visited in the species & \\
Importance Value Index for a single species & $\mathrm{pfv}$ : flowers visited by the pollinator & \\
Importance Value Index for both species & $\mathrm{TFv}_{\mathrm{sp}}=\mathrm{PV}+\mathrm{PVT}+\mathrm{PF}+\mathrm{PFT}$ & \\
\hline
\end{tabular}

Table 3. Pollinators of Fuchsia campos-portoi and F. regia at the Parque Nacional do Itatiaia, indicating the number of pollination events (Visits), the number of flowers visited (Fvisit), the average of flowers visited (F/ind), the percentages of pollination events promoted by each species $(\%$ visits) and the percentage of flowers visited by each species (\% flowers). The data for all hummingbird species are summarized in Hummingbirds.

\begin{tabular}{|c|c|c|c|c|c|c|c|c|c|c|}
\hline \multirow{2}{*}{ Pollinator } & \multicolumn{5}{|c|}{ Fuchsia campos-portoi } & \multicolumn{5}{|c|}{ Fuchsia regia } \\
\hline & Visits & Fvisit & F/ind & $\%$ visits & $\%$ flowers & Visits & Fvisit & $\mathrm{F} /$ ind & $\%$ visits & $\%$ flowers \\
\hline Bombus brasiliensis & 89 & 465 & 5,22 & 80,18 & 82,89 & 1 & 4 & 4,00 & 0,77 & 0,65 \\
\hline Hummingbirds & 16 & 78 & 11,91 & 14,41 & 13,90 & 88 & 417 & 17,75 & 67,69 & 67,80 \\
\hline Clytolaema rubricauda & 0 & 0 & 0,00 & 0,00 & 0,00 & 52 & 269 & 5,17 & 40,00 & 43,74 \\
\hline Leucochloris albicollis & 2 & 4 & 2,00 & 1,80 & 0,71 & 11 & 32 & 2,91 & 8,46 & 5,20 \\
\hline Colibri serrirostris & 5 & 19 & 3,80 & 4,50 & 3,39 & 8 & 43 & 5,38 & 6,15 & 6,99 \\
\hline Stephanoxis lalandi & 9 & 55 & 6,11 & 8,11 & 9,80 & 17 & 73 & 4,29 & 13,08 & 11,87 \\
\hline Apis mellifera & 6 & 18 & 3,00 & 5,41 & 3,21 & 22 & 92 & 4,18 & 16,92 & 14,96 \\
\hline Acroceridae & 0 & 0 & 0,00 & 0,00 & 0,00 & 19 & 102 & 5,37 & 14,62 & 16,59 \\
\hline TOTAL & 111 & 561 & 5,05 & 100 & 100 & 130 & 615 & 4,73 & 100 & \\
\hline
\end{tabular}

On the third day of anthesis the colours of the petals start getting lighter (Figure 1A). The stamen filaments progressively elongate until the fifth day (Figure 1A). At this point, all stamens have released their pollen and, in many cases, touch the stigmatic surface promoting automatic self-pollination (see Breeding system) (Figure 1A). After one day of anthesis, intact flowers of $F$. regia accumulate a mean of $45 \pm 11,4 \mu \mathrm{l}$ of nectar with a concentration of $14,5 \pm 5,7 \%$. In turn, after one day of anthesis, flowers of F. campos-portoi secrete a mean of $17 \pm 5,3 \mu \mathrm{l}$ of nectar with $20,2 \pm 2,04 \%$ of concentration (Table 5).

\section{Breeding system and natural fruit set}

Both species are self-compatible and, whereas crosspollination presented the best results, both species are clearly facultatively autogamous (Table 1), since 58,33\% of the intact flowers of $F$. regia and $43,59 \%$ of the intact flowers of $F$. campos-portoi underwent delayed selfpollination. Fuchsia campos-portoi yielded no fruits through emasculation, and $F$. regia produced a minimal $(3,57 \%)$ fruit set through this treatment, a fact that makes us consider that this result is probably a consequence of pollen contamination during manipulation. Natural fruit set (open pollination) was very high in both species $(77,35 \%$ in F. regia and $88,88 \%$ in F. campos-portoi; Table 1). No fruits were obtained through interspecific crosses $(F$. regia $\mathrm{x}$ F. campos-portoi) (Table 1). The association of the results of breeding system experiments of the two species was statistically significant $(x$-squared $=0,0012512, \mathrm{df}=\mathrm{NA}$, $\mathrm{p}$-value $=1)$, indicating differences in the results obtained for each species (Table 4). Yet, the Q-Cochran test indicates no statistical differences in the results obtained through self- and cross-pollination in F. campos-portoi $(\mathrm{Q}=0,2$, $\mathrm{df}=1, \mathrm{p}$-value $=0,6547)$ and $F$. regia $(\mathrm{Q}=0,3333, \mathrm{df}=$ $1, \mathrm{p}$-value $=0,5637)($ Table 1$)$.

\section{Pollinators and flower visitors}

\section{Overall pollination process and shared pollinators}

Pollinators and visitors of both species were observed during all daylight hours, but were more frequent between 11 and $12 \mathrm{hrs}$. As a whole, hummingbirds, bees and Acroceridae flies were recorded as pollinators (Figure 2), but with different levels of importance in each species of Fuchsia (see Table 3 and Figure 3).

The two studied Fuchsia species shared the following hummingbird pollinators: Colibri serrirostris (Vieillot, 1816), Leucochloris albicollis (Vieillot, 1818) and 
Table 4. Summary of the statistical analysis applied to the pollinator visitation and the breeding system for Fuchsia campos-portoi and F. regia at the Parque Nacional do Itatiaia. *: significant.

\begin{tabular}{|c|c|c|c|c|c|}
\hline \multirow{2}{*}{ Trait } & \multirow{2}{*}{ Test } & \multicolumn{2}{|c|}{ All pollinators } & \multicolumn{2}{|c|}{ Hummingbirds X Bombus } \\
\hline & & X-squared & p-value & X-squared & p-value \\
\hline Pollination events & Pearson's Chi-squared test with Yates's continuity correction & 163,55 & $0,0004998 *$ & 132,15 & $2,2 \mathrm{e}-16^{*}$ \\
\hline Flowers visited & Pearson's Chi-squared test with Yates's continuity correction & 836,37 & $<2,2 \mathrm{e}-16^{*}$ & 677,38 & $2,2 \mathrm{e}-16^{*}$ \\
\hline $\begin{array}{l}\text { Flowers visited/ } \\
\text { pollination event }\end{array}$ & Pearson's Chi-squared test with simulated p-value & 2,8748 & $0,0004998^{*}$ & 0,0012512 & 1 \\
\hline
\end{tabular}

Table 5. Volume and concentration (mean $\pm \mathrm{sd}$ ) of the nectar produced by bagged flowers of Fuchsia campos-portoi and F. regia (just opened and after one day of anthesis).

\begin{tabular}{lccc}
\hline & \multicolumn{2}{c}{ F. campos-portoi } & F. regia \\
\cline { 2 - 4 } & Just opened & Day 1 & Just opened \\
\hline Volume $(\mu 1)$ & $5,5 \pm 4,1$ & $17,1 \pm 5,3$ & $4,8 \pm 5,5$ \\
Concentration $(\%)$ & $10,9 \pm 5,5$ & $20,2 \pm 2,04$ & $10,9 \pm 5,5$ \\
\hline
\end{tabular}

Stephanoxis lalandi (Vieillot, 1818) (Figure 2 E-F). In addition, they shared two Apidae bee-pollinators Apis mellifera L. (introduced, non-native) and Bombus brasiliensis Lepeletier, 1836 (Figure $2 \mathrm{G}-\mathrm{H}$ ). No piercing ("robbing") behaviour by the hummingbirds or pollinating bees was detected; all these species accessed the flowers legitimately, from below (Figure $2 \mathrm{~A}$ and F). While licking the nectar, the hummingbirds contact the stamens and the stigma with the neck, the beak and the sternal region (sternotriby) (Figure 2 A-B and F-G). The beaded pollen often accumulates in large macroscopic patches on the bird's sternum (Figure $2 \mathrm{~A}-\mathrm{B}$ and F-G). Each hummingbird visits lasts for a few seconds (about 3 secs per flower). The legitimate visits by Apidae bees (A. mellifera and $B o m b u s$ ) happened either when bees actively collected the pollen and touched the stigma in the process (A. mellifera) or when the bees tried to access the nectary (Figure 2 $\mathrm{G}-\mathrm{H})$, touching the stamens and stigma (B. brasiliensis and A. mellifera). Three wasp morphospecies as well as two separate Lepidoptera species and unidentified Coleoptera were recorded as non-pollinating floral visitors in both Fuchsia species. The IVI estimated for the pollinators (Figure 3) shows $B$. brasiliensis as the most important pollinator for F. campos-portoi (IVI $=2.4$, see Figure 3) and the hummimgbirds for $F$. regia $(\mathrm{IVI}=2.14$ see Figure 3 ), although they pollinated both Fuchsia species. The bees of $A$. mellifera appeared pollinating both species but their importance is higher in F. regia; in F. campos-portoi this is the less important pollinator. The Acroceridae flies only appeared as pollinator of $F$. regia, with a low IVI (Figure 3).

Fuchsia regia: in total, seven pollinator species were recorded (Table 3). The hummingbirds Clytolaema rubricauda (Boddaert, 1783) (Figure 2 A-B), L. albicollis, $S$. lalandi and C. serrirostris were the most frequent pollinators (Table 3). Hummingbirds, as a whole, account for $67,8 \%$ of the visited flowers $(n=417)$ (Table 3$)$. Additionally, Acroceridae flies (Figure 2C) and, to a lesser extent, bees of $A$. mellifera and $B$. brasiliensis pollinated the remainder (Table 3). Only L. albicollis and Apis mellifera were recorded at the three altitudinal ranges (Table 3 ). The other hummingbird species were recorded in two altitudinal ranges and the bee $B$. brasiliensis was recorded at the second range, only. Considering hummingbirds alone, $C$. rubricauda was responsible for $59 \%$ of the pollination events $(\mathrm{n}=52)$ and $43,7 \%$ of the visited flowers $(\mathrm{n}=$ 269). This hummingbird often displayed a territorialist behaviour, visiting all available flowers and perching nearby, defending the plants against other hummingbirds and other animals (including insects and passerine birds that were seeking the fruits). The other hummingbird species presented a "trap-lining" behaviour, visiting relatively few flowers and quickly leaving the plant. Leucochloris albicollis consistently visited few flowers at the three altitudinal ranges (as a whole, 11 pollination events and $\mathrm{n}$ $=32$ flowers, 5,20\%). Colibri serrirostris and S. lalandi promoted few pollination events $(\mathrm{n}=43$ flowers, $6,99 \%$ and $\mathrm{n}=73$ flowers, $11,87 \%$, respectively; Table 3 ) and consistently pollinated a few flowers per visitation event. Acroceridae flies were solely recorded as pollinators in $F$. regia. These flies always briefly hovered in front of the flowers (Figure $2 \mathrm{C}-\mathrm{D}$ ) and then landed onto the stamens and/or the stigma in their way to access the nectary with the proboscis. In the process they touched the stigma and the stamens, often leaving the flowers with clumps of pollen on their legs. These flies visited few flowers in each pollination event and their presence was noticed only during the months of September and October. Two passerine birds (Poospiza lateralis (Nordmann, 1835) and P. thoracica (Nordmann, 1835)) were observed piercing the hypanthium to reach the nectar. Eventually, bees of $A$. mellifera used the holes made by these birds to reach the nectar, too. The birds Spinus magellanicus (Vieillot, 1805) (Fringiliidae), Stephanophorus diadematus (Temminck, 1823) (Thraupidae) and Tangara sayaca (Linnaeus, 1766) (Thraupidae) were recorded foraging on fruits at different stages of maturation and may act as a natural disperser. 
Fuchsia campos portoi: as a whole, five pollinator species were recorded, four of them occurring at the two altitudinal ranges where $F$. campos-portoi occurs. Unlike $F$. regia, the most frequent pollinators were bees of $B$. brasiliensis, they were responsible for $80,18 \%$ of the pollination events and visited $82,88 \%$ of the monitored flowers (Table 3$)$. The hummingbirds $S$. lalandi $(8,1 \%$ of the pollination events; visiting $9,8 \%$ of the flowers; Table 3), C. serrirostris (4,5\% of the pollination events, pollinating $3,3 \%$ of the flowers; Table 3 ), bees of $A$. mellifera $(5,4 \%$ of the pollination events, visiting $3,2 \%$ of the flowers) and L. albicollis $(1,8 \%$ of the pollination events, $0,7 \%$ of the flowers) followed in importance (Table 3 ). The latter hummingbird species was found at altitudes between 2100 and $2300 \mathrm{~m}$ only. All the other pollinators were recorded at the two altitudinal ranges. None of the hummingbirds recorded at $F$. campos-portoi performed territorial/defensive displays, all of them utilizing a "traplining" pollinator behaviour. Neither animals piercing the hypanthium nor putative seed dispersers were recorded during our observations.

The association between the pollination events and the number of flowers visited per pollination event was significant when considering the whole pollinator assemblage of the two studied species (Table 4). Yet, the association wasn't significant when comparing hummingbirds and bumblebees alone (Table 4).

\section{DISCUSSION}

\section{Floral features}

From a morphological point of view, overall flower features (both, floral morphology and nectar features) of F. regia and F. campos-portoi are consistent with those already reported for Fuchsia species from sect. Quelusia (Arizmendi et al.1996, Berry 1989, Rodrigues \& Singer 2014, Travesset et al.1998). Protogyny has already been cited by Berry (1989) as a widespread character in the Fuchsia sect. Quelusia. Protogyny theoretically promotes cross-pollination and consists in a temporal separation on the functionality of flower's fertile whorls, where the gynoecium matures first (Endress 1994). Consequently, in protogynous species, the flowers act as pollen-receivers first and, after a variable time, as pollen-donors (Endress 1994). Colour change in petals has already been documented in flowers of $F$. regia subsp. reitzii P. E. Berry and $F$. regia subsp. serrae P. E. Berry, from Rio Grande do Sul, Southern Brazil (Rodrigues \& Singer 2014). In these flowers, the petals of the fresh, just-opened flowers are dark purplish turning later into a lighter colouration, as we herein report for both studied species. In F. excorticata L. f., from New Zealand, the petals change from green to a red coloration and, at the latter phase, the flowers are ignored by their avian pollinators (Delph \& Lively 1989; Robertson et al. 2008). In the species we studied, however, color changes are not apparently correlated with changes in pollinator behaviour. During the observations presented herein, not evident differences were perceived on the visitation of flowers with different petal colors. In agreement with this, a video record of the hummingbird pollinators of $F$. regia in Rio Grande do Sul (Southern Brazil) suggests that the birds spend essentially the same time at the flowers with both dark and light petal color (Singer, pers. comm.).

\section{Breeding system}

Fuchsias have been generically considered as outcrossing (Raven, 1979) and self-compatible (Berry 1989, Raven 1979). Nowadays, comparatively few species have been studied in detail regarding their actual breeding systems; in spite of the commercial importance of the group (Berry et al.2004). The genus is considerably diversified regarding breeding strategies. Arroyo \& Raven (1975) reported gynodioecy (individuals with perfect flowers coexisting with individuals with functionally female flowers) in Mexican populations of $F$. thymifolia Kunth and F. microphylla Kunth. Gynodioecy was also documented for F. lycioides Andrews, from Chile (Atsatt \& Rundel 1982). A similar condition was reported for populations of $F$. excorticata, from New Zealand (functionally female flowers presenting shorter, non-functional stamens) (Delph \& Lively 1989, Robertson et al. 2008) and for $F$. perscandens Cockayne \& Allan, also from New Zealand (Montgomery et al. 2001). Cuevas et al. (2014) report the existence of "subdioecy" in F. microphyla, from México. In these populations, there are individuals with perfect flowers as well as individuals whose flowers are either functionally male or female (Cuevas et al. 2014). A similar condition was previously reported in populations of $F$. procumbens R. Cunn ex A. Cunn, from New Zealand (Godley1963). In addition, a few Mexican species (such as F. obconica Breedlove and $F$. parviflora Lindl.) are truly dioecious (González et al. 2018). Using a well-supported phylogeny of Fuchsia as a framework, Berry et al. (2004) proposed that male sterility (individuals whose flowers present staminodia, thus acting solely as pollen-receivers) arisen in the Sections Encliandra (Zucc) Lindm., Kierschlegeria (Spach) Munz and Schufia (Spach) Munz; comprising all of Mexican-Central American distribution. According to Berry et al. (2004), female sterility (individuals with flowers acting as pollen-donors only) evolved in F. cylindracea Lindl. (Section Enclyandra (Zucc.) Lindm., a Mexican-Central American Clade) and F. procumbens (Sect. Procumbentes E. J. Godley \& P. E. Berry; a lineage from the Southern Pacific). In spite of being protogynous, the two studied species are clearly monoecious and present perfect flowers (this is, with functional androecium and gynoecium). From what can be inferred from the bibliographic references, both conditions (perfect flowers and protogyny) may be the rule for all the remaining species within the Section Quelusia (see Berry 1989). This is a remarkable contrast with the aforementioned diversity in breeding system strategies.

Remarkably, the two studied species couple protogyny (a feature likely promoting cross-pollination, see Endress 
1994) with delayed self-pollination. Tsitrone et al. (2003) have hypothesized that under certain circumstances, such as pollinator scarcity and absence of inbreeding depression, delayed self-pollination can evolve in modally outcrossing species, as a way to circumvent the absence or rarity of pollinators. Goodwillie \& Weber (2018) reviewed the literature on delayed self-pollination and concluded that this strategy serves in some circumstances (but not in all) as a "best of two worlds" strategy that helps plants to overcome adverse conditions. Since there is a variable time until self-pollination takes place, opportunities exist for outcrossing. If animal-mediated pollination doesn't happen, delayed self-pollination causes some fruit and seed production (Goodwillie \& Weber 2018). According to Goodwillie \& Weber (2018), delayed self-pollination is frequent in Arctic and Alpine habitats, a pattern that is consistent with the distribution of the two studied species and the remaining taxa in the Section Quelusia (Berry 1989).Goodwillie \& Weber (2018) reviewed 65 published reports involving 63 angiosperm species, none of them involving species of Fuchsia. Thus, to the best of our knowledge, the present contribution is the first documented report of delayed self-pollination for the genus. We would like to emphasize that in the two studied species anther dehiscence starts only after the third day of blooming. Since the flowers of both species are protogynous (the stigma is already receptive in just-opened flowers) and the flowers act solely as pollen-receivers for three days, there are ample opportunities for animal-mediated pollination to happen until automatic self-pollination takes place. Since pollinators were recorded for the two studied species, it seems plausible that a significant part of the natural fruit set is a consequence of animal-mediated pollination.

\section{Pollinators and pollinator behaviour}

The two studied species share a number of flower features (unscented, reddish, tubular, pendent nectariferous flowers) that likely fit very well within the syndrome of ornithophily (bird pollination) (Faegri \& van der Pijl 1979, Buzato et al. 2000). In fact, based on these flower features and on the observation of hummingbird visits, Fuchsia species of Section Quelusia have largely been considered as primarily pollinated by birds (Berry 1989, Raven 1979, Buzato et al. 2000). Our results indicate that both studied species are, in fact, pollinated by hummingbirds, but not exclusively by them. In fact, according to our observations, the most important pollinators of $F$. campos porto $i$ are native bumblebees of $B$. brasiliensis, with smaller contributions of hummingbirds and $A$. mellifera. These findings promote the discussion regarding the effectiveness of floral syndromes to predict the pollinators. This question has been strongly debated, with researchers often supporting very different or opposite views. A number of authors, in fact, support that floral syndromes are effective pollinator predictors (Rosas-Guerrero et al. 2014, Fenster et al. 2004), whereas others (Ollerton et al. 2009, Maruyama et al. 2013) adopt a more cautious approach. Maruyama et al. (2013), for instance, document a number of plant species with flowers bearing no "hummingbird features" that are, indeed visited and pollinated by hummingbirds in the Brazilian Cerrado. This kind of evidence highlights the dynamic nature of the interactions between the flowers and their visitors/ pollinators. Ashworth et al. (2015) proposed a remarkably interesting approach to this question. According to these authors (Ashworth et al. 2015), pollination "syndromes" are the evolutionary consequence of convergences in floral traits mediated by the pollinators. In plants with more than one possible pollinator, rather than predicting all the pollinators, pollination syndromes accurately predict the more effective ones (Ashworth et al. 2015). In these plants, secondary pollinators tend to be less effective (Ashworth et al.2015).

As commented above, hummingbird pollination in $F$. regia was already reported by Buzato et al (2000) that documented four species visiting flowers in Southeastern Brazil. All these birds bore F. regia pollen on the bill, the neck or the sternum (Buzato et al.2000), much as we observed for the hummingbird pollinators of $F$. regia and $F$. campos-portoi at the Itatiaia Mountains. Notably, the most frequent hummingbird pollinators of $F$. regia (C. rubricauda) often exhibited aggressive, territorial behaviour; defending the plants against other hummingbirds and other animals as well. These defending males perched near the plants and visited them regularly, probing most available flowers in the process. Such a behaviour certainly promotes a considerable degree of geitonogamous selfpollination (flowers pollinated with the pollen of the same individual). Since the plants are self-compatible, a considerable amount of animal-mediated self-pollination is very likely. All the other hummingbird pollinators of $F$. regia performed a "trap-lining" behaviour, visiting a few flowers per pollination event and leaving the plant quickly after these visits. None of the hummingbird pollinators of F. campos-portoi displayed territorial behaviors, all of them presenting "trap-lining" visitation patterns. Fuchsia magellanica, the only Patagonian species of Section Quelusia is either reported as pollinated by hummingbirds of Sephanoides galeritus (Lesson \& Garnot, 1827) (Travesset et al. 1989) or by hummingbirds and native bumblebees of $B$. dahlbomii Guérin-Méneville, 1835 (Valdivia et al. 2016), but evidence substantiating these statements is still lacking. Exclusive pollination by hummingbirds was also reported for the Chilean F. lycioides that relies on a single pollinator species (Rhodopis vesper Lesson, 1829) (Atsatt \& Rundel. 1982). Pollination by Meliphagidae birds is well documented in F. excorticata and F. perscandens; both from New Zealand (Delph \& Lively1989, Montgomery et al. 2001, Robertson et al. 2008).

To the best of our knowledge, this is the first report of insect pollination in Brazilian species of Fuchsia Section Quelusia, and the first report of Acroceridae flies as Fuchsia pollinators as well. Yet, there are some reports involving insect pollination in some Mexican Fuchsia 
species. The Mexican dioecious F. parviflora is visited by both, hummingbirds and bumblebees (González et al. 2018) and the similarly dioecious F. obconica is reported to be visited by several Diptera. Fuchsia microphylla is principally pollinated by bees of Bombus ephippiatus Say, 1837 and Deltoptila sp. (Cuevas et al. 2014).

During the present observations, both studied Fuchsia species shared five species of pollinators (three hummingbirds and two bees). Thus, theoretically, animalmediated interspecific crosses are possible. However, all controlled interspecific crosses aborted (Table 1). A higher number of such crosses as well as a detailed reanalysis of the reputed hybrids are highly desirable in order to address this question more appropriately.

\section{CONCLUSIONS}

This is the first detailed report coupling detailed pollination observations and breeding system experiments for two species of Fuchsia Section Quelusia. At the Introduction, we formulated three explicit hypotheses: 1) That the study plants were pollinator-dependent, 2) That, owing to their floral features, the pollinators of both species should be hummingbirds or other birds, and 3 ) That the study plants should be self-compatible, yet pollinatordependent. In the light of the results we obtained, we can conclude that the hypothesis 1) is to be rejected, since a significant part of the intact flowers of both studied species can undergo delayed self-pollination. So, from a strict point of view, pollinators are not compulsory for the plants to set fruit, even though all evidence indicates that animalmediated pollination is taking place in both species. The hypothesis 2) was partially confirmed. Hummingbirds were found as pollinators in both species. Yet, other animal pollen-vectors (insects) were found and, in the specific case of F. campos-portoi, hummingbirds were not the most frequent pollinators. The hypothesis 3 ) was partially confirmed, as well. The breeding experiments evidenced that both Fuchsia species are indeed self-compatible (able to set fruit and seed following pollination with the pollen of the same individual). However, as explained in 1), a significant part of the flowers self-pollinate without the agency of animal pollen-vectors. Both studied species share some features (self-compatibility, delayed self-pollination and pollinator non-specificity) that are likely adaptive or advantageous in alpine (high altitude) environments, where pollinators can become absent or rare. For plants with these features, pollinators aren't completely necessary, but are fundamental for cross-pollination and its beneficial effects.

\section{ACKNOWLEDGEMENTS}

This contribution is part of the first author's M. Sc. Dissertation at the Programa de Pós-Graduação em Ciências Ambientais e Florestais-UFRRJ. The authors want to acknowledge the staff of the Parque Nacional do Itatiaia for logistical support during fieldwork. The authors thank SISBIO-ICMBIO for working and collecting permit. Ken Archer (Prescott, Arizona) is thanked for English improvement. Two anonymous reviewers are also thanked for their constructive suggestions.

\section{REFERENCES}

Abidin, Z., Leksono, A. S., \& Kusuma, Z. 2013. The effect of refuge block on the insect visitors to apple crop in Batu, East Java. Journal of Biodiversity and Environmental Sciences (JBES) 3(12) 20-24.

Arizmendi, M. C., Dominguez, C. A., \& Dirzo, R. 1996. The role of an avian nectar robber and of hummingbird pollinators in the reproduction of two plant species. Functional Ecology 10 (1): 119-127.

Arroyo, M. T. K., \& Raven, P. H. 1975. The evolution of subdioecy in morphologically gynodioecious species of Fuchsia sect. Encliandra (Onagraceae). Evolution 29: 500-511.

Ashworth, L., Aguilar, R., Martén-Rodríguez, S., Lopezaraiza-Mikel, M., Avila-Sakar, G., Rosas-Guerrero, V., \& Quesada, M. 2015. Pollination syndromes: a global pattern of convergent evolution driven by the most effective pollinator. In Evolutionary biology: biodiversification from genotype to phenotype. Springer, Cham. p. 203-224.

Atsatt, P. R., \& Rundel, P. W. 1982. Pollinator maintenance vs. fruit production: partitioned reproductive effort in subdioecious Fuchsia lycioides. Annals of the Missouri Botanical garden 69: 199-208.

Berry P.E. 1989. A systematic revision of Fuchsia sect. Quelusia (Onagraceae). Annals of the Missouri Botanical Garden 76(2):532584.

Berry, P. E., Hahn, W. J., Sytsma, K. J., Hall, J. C., \& Mast, A. 2004. Phylogenetic relationships and biogeography of Fuchsia (Onagraceae) based on noncoding nuclear and chloroplast DNA data. American Journal of Botany 91(4): 601-614.

Buzato, S., Sazima, M., \& Sazima, I. 2000. Hummingbird-Pollinated Floras at Three Atlantic Forest Sites 1. Biotropica, 32(4b), 824-841.

Cuevas, E., Jiménez, R., \& Lopezaraiza-Mikel, M. 2014. Sex-specific reproductive components and pollination ecology in the subdioecious shrub Fuchsia microphylla. Plant Biology 16(6): 1096-1103.

Delph, L. F., \& Lively, C. M. 1989. The evolution of floral color change: pollinator attraction versus physiological constraints in Fuchsia excorticata. Evolution, 43(6):1252-1262.

Endress, P. K. 1996. Diversity and evolutionary biology of tropical flowers. Cambridge University Press. 420 p.

Faegri, K., \& Van der Pijl, L. 1979. The Principles of Pollination Ecology. 3rd edn. Pergamom. $256 \mathrm{p}$.

Fenster, C. B., Armbruster, W. S., Wilson, P., Dudash, M. R., \& Thomson, J. D. 2004. Pollination syndromes and floral specialization. Annu. Rev. Ecol. Evol. Syst., 35, 375-403.

Godley, E. J. 1963. Breeding systems in New Zealand plants: 2. Genetics of the sex forms in Fuchsia procumbens. New Zealand journal of botany $1(1): 48-52$.

Goodwillie, C., \& Weber, J. J. 2018. The best of both worlds? A review of delayed selfing in flowering plants. American Journal of Botany, 105(4):641-655.

González, C., Alvarez-Baños, A., \& Cuevas, E. 2018. Floral biology and pollination mechanisms of four Mexico-endemic Fuchsia species with contrasting reproductive systems. Journal of Plant Ecology 11(1):123-135.

Hervé, M., \& Hervé, M. M. 2020. Package 'RVAideMemoire'. Available from: https://CRAN. R-project.org/package= RVAideMemoire. Accessed on July 16, 2020

Kearns, C. A., \& Inouye, D. W. 1993. Techniques for pollination biologists. University press of Colorado. 583 p.

Maruyama, P. K., Oliveira, G. M., Ferreira, C., Dalsgaard, B., \& Oliveira, P. E. 2013. Pollination syndromes ignored: importance of non-ornithophilous flowers to Neotropical savanna hummingbirds. Naturwissenschaften, 100(11):1061-1068.

Montgomery, B. R., Kelly, D., \& Ladley, J. J. 2001. Pollinator limitation of seed set in Fuchsia perscandens (Onagraceae) on Banks Peninsula, South Island, New Zealand. New Zealand Journal of Botany, 39(4):559-565. 
Ollerton, J., Alarcón, R., Waser, N. M., Price, M. V., Watts, S., Cranmer, L., Hingston A, Peter C. I. \& Rotenberry, J. 2009. A global test of the pollination syndrome hypothesis. Annals of Botany, 103(9):14711480.

Pilger, R., \& Schulze, G. 1935. Uma nova especie de Fuchsia do Itatiaya. Rodriguesia 1(2): 95-95.

Raven, P. H. 1979. A survey of reproductive biology in Onagraceae. New Zealand Journal of Botany 17(4):575-593.

Robertson, A. W., Ladley, J. J., Kelly, D., McNutt, K. L., Peterson, P. G., Merrett, M. F., \& Karl, B. J. 2008. Assessing pollination and fruit dispersal in Fuchsia excorticata (Onagraceae). New Zealand Journal of Botany 46(3): 299-314.

Rodrigues, D., \& Singer, R. B. 2014. As subespécies de Fuchsia regia (Vand. ex Vell.) Munz (Onagraceae) ocorrentes no Rio Grande do Sul, Brasil. Iheringia. Série Botânica 69(2):257-266.

Rosas-Guerrero, V., Aguilar, R., Martén-Rodríguez, S., Ashworth, L., Lopezaraiza-Mikel, M., Bastida, J. M., \& Quesada, M. 2014. A quantitative review of pollination syndromes: do floral traits predict effective pollinators?. Ecology letters 17(3):388-400.

RStudio: Integrated development environment for R [Internet]. Boston, MA: R Studio; 2012. Available from: http://www.rstudio.org. Accessed on July 16, 2020

Travesset A, Wilson M.F. \& C. Sabag 1998. Effect of nectar-robbing on fruit set of Fuchsia magellanica in Tierra del Fuego: a disrupted mutualism. Functional Ecology 12:459-464.

Tsitrone, A., Duperron, S., \& David, P. 2003. Delayed selfing as an optimal mating strategy in preferentially outcrossing species: theoretical analysis of the optimal age at first reproduction in relation to mate availability. The American Naturalist 162(3):318-331.

Valdivia, C. E., Carroza, J. P., \& Orellana, J. I. 2016. Geographic distribution and trait-mediated causes of nectar robbing by the European bumblebee Bombus terrestris on the Patagonian shrub Fuchsia magellanica. Flora-Morphology, Distribution, Functional Ecology of Plants 225:30-36. 